\title{
PENGARUH KOIMPETENSI LEADERSHIP GURU PENDIDIKAN AGAIMA ISLAM TERHADAP MOTIVASI BELAJAR PESERTA DIDIK KELAS XI DI SMA NEGERI 1 IMAMUJU
}

\author{
Qurrata A'yun Anwar', Saprin², Idah Suaidah ${ }^{3}$ \\ Universitas Islam Negeri Alauddin Makassar
}

\begin{abstract}
This study aims to determine the Leadership Competencies of Islamic Religious Education Teachers at SMA Negeri 1 Mamuju, to determine the Learning Motivation of Class XI Students at SMA Negeri 1 Mamuju, and to determine the Effect of Leadership Competencies of Islamic Religious Education Teachers on the Learning Motivation of Class Xi Students in SMA State 1 Mamuju. This type of research is a quantitative descriptive research. The population in this study were all students of class XI at SMA Negeri 1 Mamuju, totaling 370 students, while the sample was $15 \%$ of the population of 56 students with the "Simple Random Sampling" sampling technique. The instrument used in this research is the scale of leadership competence and the scale of learning motivation. The data analysis technique used is descriptive statistical analysis, the leadership competence of Islamic Religious Education teachers obtained an average value of 43.48 in the medium category, from 100 the lowest score was 29 and the highest score was 55 with a percentage of $60.71 \%$. While descriptive statistical analysis for the learning motivation of class XI students obtained an average score of 65.85 in the medium category, from 100 the lowest score was 52 and the highest score was 80 with a percentage of $73.21 \%$. As for the results of inferential statistical analysis with a simple linear regression test, the correlation coefficient of tcount is 3,262 while the value of ttable (5\%) $(d f=56)$ so that ttable is 1,673. So, it can be concluded that tcount ttable is 3.262 1.673, then Ho is rejected and H1 is accepted which means that there is a positive influence between the leadership competence of Islamic Religious Education teachers on the learning motivation of class XI students at SMA Negeri 1 Mamuju with a contribution of $16.5 \%$.
\end{abstract}

Keywords: Leadership Competence, Learning Motivation

\section{PENDAHULUAN}

Pendidikan merupakan segala usaha yang dilakukan secara sadar guna mengurus, mengatur, memperbaiki dan mengembangkan segala sesuatu atau kemampuan yang dimiliki oleh seseorang sejak lahir agar tumbuh dan berkembang menjadi lebih baik sesuai dengan apa yang diharapkan.

Pendidikan menjadi salah satu wadah dalam menimbah ilmu pengetahuan, membentuk nilai-nilai sikap dan kepribadian yang baik serta mengembangkan kemampuan yang dimiliki oleh setiap individu. Salah satu tempat yang digunakan untuk mengembangkan kemampuan adalah di sekolah. Setiap sekolah memerlukan suatu pimpinan yang akan mengatur jalanya proses pembelajaran. 
Seseorang yang berperan penting dalam mengembangkan Pendidikan di sekolah adalah guru. Karena guru sebagai pendidik atau pengajar di sekolah yang akan mencerdaskan dan mengembangkan kemampuan masing-masing peserta didik. Guru merupakan pemegang peranan utama dalam proses belajar mengajar. Untuk menjadi seorang guru harus memiliki keahlian khusus karena guru merupakan jabatan atau profesi. Jadi pekerjaan guru tidak dapat dilakukan oleh sembarang orang yang tidak memiliki keahlian untuk melakukan kegiatan atau pekerjaan sebagai guru. ${ }^{1}$

Guru juga memiliki peranan penting dalam melahirkan generasi penerus yang mampu menjadi pemimpin di muka bumi. Oleh karena itu, guna memegang amanah tersebut guru diharapkan wajib memiliki kompetensi yang baik, berkaitan dengan tugas dan tanggung jawabnya. Oleh karena itu, untuk membentuk sikap dan kepribadian peserta didik menjadi manusia yang beriman dan bertakwa, diperlukan guru yang profesional, yaitu guru yang menguasai kompetensi di bidangnya.

Sehubung dengan hal di atas, dalam Undang-Undang Republik Indonesia Nomor 14 tahun 2005 tentang guru dan dosen, yaitu:

"Kompetensi guru meliputi kompetensi pedagogik, kompetensi kepribadian, kompetensi sosial, dan kompetensi profesional. Keempat kompetensi tersebut merupakan syarat yang mesti dimiliki oleh guru."2

Berdasarkan keputusan undang-undang yang ada di atas, maka seorang guru dalam melaksanakan tugasnya, wajib memiliki empat kompetensi tersebut, yakni kompetensi pedagogik, kompetensi kepribadian, kompetensi sosial, dan kompetensi profesional.

Lebih terkhusus kepada guru Pendidikan Agama Islam karena guru dituntut untuk mempunyai kompetensi tambahan yakni kompetensi Kepemimpinan (Leadership). Jadi guru Pendidikan Agama Islam harus memiliki lima kompetensi yakni Kompetensi Pedagogik, Komptenensi Kepribadian, Kompetensi Sosial, Kompetensi Profesional dan Kompetensi Kepemimpinan (Leadership).

Kepemimpinan merupakan suatu proses dengan berbagai cara untuk mempengaruhi orang atau sekelompok orang dalam mencapai suatu tujuan bersama. Kepemimpinan dengan pendidikan sangat berkaitan karena guru yang sepenuhnya memegang kepemimpinan di dalam kelas. Guru harus menjadi pemimpin yang bertanggung jawab terhadap peserta didiknya. Mengarahkan dan mengembangkan kemampuan yang dimiliki setiap peserta didik serta membentuk kepribadian yang baik.

Seiring dengan perkembangan zaman, ilmu dan teknologi semakin berkembang pesat dan arus globalisasi juga semakin meningkat maka muncullah persaingan dalam bidang pendidikan. Sampai saat ini mata pelajaran Pendidikan Agama Islam masih

\footnotetext{
${ }^{1}$ Ahmad Sabri, Strategi Belajar Mengajar\& Micro Teaching (Ciputat: Quantum Teaching, 2007), h.56.

${ }^{2}$ Republik Idonesia, "Undang-Undang Republik Indonesia Nomor 14 Tahun 2005 tentang Guru dan Dosen”, (Jakarta: 2005), h. 6.
} 
kurang disukai oleh peserta didik. Apabila guru memiliki kompetensi kepemimpinan yang baik, maka akan menumbuhkan rasa suka peserta didik terhadap gurunya. Sehingga tanpa disadari akan muncul sendiri motivasi atau keinginan peserta didik untuk menyukai mata pelajaran Pendidikan Agama Islam.

Kunci utama dalam menciptakan pendidikan yang bermutu dalam upaya membangun bangsa adalah dengan menciptakan pembelajaran yang berpegang pada sistem nasional. Pembelajaran adalah kegiatan yang dilakukan oleh seorang guru yang yang bertujuan untuk menumbuhkan dan mengembangkan potensi diri dan keterampilan yang dimiliki oleh peserta didik.

Dalam proses pembelajaran, bukan hanya guru yang bertindak sebagai pelaku utama yang menentukan keberhasilan pembelajaran tersebut. Akan tetapi peserta didik juga menentukan keberhasilan suatu pembelajaran. Apabila di dalam diri seorang peserta didik ada niatan atau keinginan untuk belajar, keinginan dan dorongan inilah yang dikatakan sebagai motivasi.

Dalam proses pembelajaran motivasi sangat besar pengaruhnya. Dengan adanya motivasi dapat menimbulkan keinginan dan kegairahan peserta didik dalam mengikuti pembelajaran. Motivasi belajar adalah keseluruhan daya penggerak psikis dalam diri peserta didik yang menimbulkan aktivitas belajar atau kegiatan belajar dengan rasa yang lebih bergairah dan bersemangat dalam mencapai suatu hasil dan tujuan yang ingin dicapai. Oleh karena itu, motivasi sangat penting untuk mendorong peserta didik dalam kegiatan belajar. Ada banyak faktor yang dapat menimbulkan motivasi belajar peserta didik salah satunya adalah faktor guru sebagai seorang pemimpin di dalam kegiatan pembelajaran.

Dari hasil observasi peneliti di SMA Negeri 1 Mamuju, pada tanggal 15 Februari 2020, penulis melihat masih banyak peserta didik yang kurang memiliki motivasi belajar terkhusus pada mata pelajaran Pendidikan Agama Islam. Penulis mengamati secara langsung bagaimana peserta didik dalam mengikuti pembelajaran. Adapun masalah yang ditemukan oleh peneliti dalam melakukan observasi awal yaitu kurangnya motivasi belajar peserta didik disebabkan kurangnya ketertarikan peserta didik dalam mengikuti pembelajaran Pendidikan Agama Islam. Hal tersebut yang menyebabkan peserta didik memiliki rasa acuh tak acuh dalam mengikuti proses pembelajaran, serta peserta didik tidak mengerjakan tugas yang diberikan. Kebanyakan dari peserta didik yang merasa bosan dalam mengikuti pembelajaran Pendidikan Agama Islam. Hal tersebut dikarenakan banyaknya peserta didik yang tidak memiliki motivasi dalam belajar. Dengan demikian, peserta didik perlu mendapatkan dorongan dalam dirinya untuk menumbuhkan motivasi belajar.

Pada dasarnya penanaman jiwa kepemimpinan pada guru Pendidikan Agama Islam adalah hal yang sangat penting dilakukan. Dengan kepemimpinan yang dimiliki guru, maka guru Pendidikan Agama Islam dalam menjalankan tugasnya, diharuskan memiliki kemampuan menjadi inovator, motivator, fasilitator, dan konselor, serta guru juga 
diharuskan memiliki kemampuan untuk mengendalikan dan mengarahkan. Apabila guru Pendidikan Agama Islam kompetensi leadership yang baik, maka akan menumbuhkan rasa suka peserta didik terhadap gurunya. Sehingga tanpa disadari akan muncul sendiri motivasi atau ketertarikan dan kegairahan peserta didik pada mata pelajaran Pendidikan Agama Islam.

Dari hasil observasi di atas, maka penulis tertarik untuk melakukan penelitian berjudul "Pengaruh Komptenesi Leadership guru Pendidikan Agama Islam terhadap Motivasi Belajar Peserta Didik Kelas XI di SMA Negeri 1 Mamuju”.

\section{METODOLOGI PENELITIAN}

Jenis penelitian yang digunakan yaitu penelitian deskriptif kuantitatif ex post facto. Lokasi penelitian bertempat di SMA Negeri 1 Mamuju, tepatnya di kelas XI IPA dan XI IPS. Sekolah ini berlokasi di jalan Kumbang Lollo Nomor 01, Kelurahan Binanga, Kecamatan Mamuju, Kabupaten Mamuju, provinsi Sulawesi Barat. Populasi dalam penelitian ini adalah keseluruhan peserta didik kelas XI IPA IPS di SMA Negeri 1 Mamuju yang berjumlah 370 orang peserta didik.

\section{TINJAUAN TEORETIS}

\section{A. Kompetensi Leadership Guru Pendidikan Agama Islam}

\section{Pengertian Kompetensi}

Kompetensi dalam bahasa Inggris, yaitu "Competence" yang memiliki arti kecakapan dan kemampuan. Menurut kamus besar Bahasa Indonesia kompetensi adalah kewenangan (kekuasaan) untuk menentukan dan memutuskan sesuatu, jika kompetensi berarti kemampuan dan kecakapan, maka hal ini berarti memiliki kaitan erat dengan pemilikan pengetahuan dan kecakapan atau keterampilan sebagai guru. ${ }^{3}$

Kompetensi merupakan peleburan dari pengetahuan (daya pikir), sikap (daya kalbu) dan keterampilan (daya psikis) yang diwujudkan dalam bentuk perbuatan. Dengan kata lain, kompetensi merupakan perpaduan dari penguasaan pengetahuan, keterampilan, nilai dan sikap yang direfleksikan dalam kebiasaan berpikir dan bertindak dalam melaksanakan tugas atau pekerjaannya. ${ }^{4}$

${ }^{3}$ Pusat Bahasa Depdikbud, Kamus Besar Bahasa Indonesia (Cet. III; Jakarta: Balai Pustaka, 2005), h. 584.

${ }^{4}$ Syaiful Sagala, Kemampuan Profesional Guru dan Tenaga Kependidikan (Cet. IV; Bandung, Alpabeta, 2013), h. 23. 


\section{B. Pengertian Kompetensi Leadership Guru Pendidikan Agama Isalam}

Kompetensi leadership (kepemimpinan) guru adalah kemampuan seorang guru untuk mempengaruhi peserta didik yang di dalamnya berisi serangkaian tindakan atau perilaku tertentu terhadap peserta didik yang dipengaruhinya.

Kompetensi leadership guru Pendidikan Agama Islam adalah kemampuan yang dimiliki oleh seorang guru dalam mengatur, mengarahkan, membina dan mempengaruhi peserta didik dalam proses pembelajaran maupun dalam pembudayaan pengamalan ajaran agama Islam di sekolah agar tugasnya sebagai seorang guru dapat terlaksana dengan baik sesuai dengan apa yang telah direncanakan.

Kompetensi guru Pendidikan Agama Islam secara lebih rinci diterangkan oleh Menteri Agama melalui Keputusan Menteri Agama Nomor 211 Tahun 2011 (KMA 211/2011) tentang Pedoman Pengembangan Standar Pendidikan Agama Islam Pada Sekolah. Dalam bab IV huruf B nomor 2 dinyatakan bahwa ruang lingkup pengembangan standar kompetensi guru Pendidikan Agama Islam (PAI) pada PAUD/TK, SD, SMP dan SMA/SMK meliputi:

Kompetensi pedagogik adalah kemampuan guru dalam mengelola pembelajaran, Kompetensi kepribadian adalah kemampuan kepribadian guru yang mantap, berakhlak mulia, arif dan berwibawa serta menjadi teladan peserta didik. Kompetensi sosial adalah kemampuan guru untuk berkomunikasi dan berinteraksi secara efektif dan efisien dengan peserta didik, sesama guru, orang tua/wali peserta didik dan masyarakat sekitar. Kompetensi professional adalah kemampuan guru dalam kemampuan penguasaan materi pelajaran secara luas dan mendalam. Kompetensi leadership adalah kemampuan guru untuk mengorganisasikan potensi unsur sekolah secara sistematis untuk mendukung pembudayaan pengamalan ajaran agama pada satuan Pendidikan. ${ }^{5}$

Berdasarkan keputusan Menteri Agama di atas, maka dapat disimpulkan bahwa ada lima kompetensi yang harus dimiliki oleh guru Pendidikan agama Islam, yaitu kompetensi pedagogik, kompetensi kepribadian, kompetensi sosial, kompetensi profesional, dan kompetensi leadership (kepemimpinan). Kompetensi-kompetensi guru Pendidikan Agama Islam yang telah ditentukan oleh Keputusan Menteri Agama (KMA) dapat dijadikan sebagai dasar ukuran observasi sehingga dapat ditentukan dan dinilai guru yang telah memiliki kompetensi penuh dengan guru yang masih kurang memadai kompetensinya.

Adapun menurut Peraturan Menteri Agama Nomor 16 Tahun 2010 Pasal 16, menyatakan kompetensi kepemimpinan adalah kemampuan seorang guru untuk mempengaruhi peserta didik yang di dalamnya berisi serangkaian tindakan atau perilaku tertentu terhadap peserta didik yang dipengaruhinya. Indikator kompetensi kepemimpinan yang harus dimiliki oleh seorang guru PAI adalah:

\footnotetext{
${ }^{5}$ Kementerian Agama RI, Peraturan Menteri Agama Republik Indonesia tentang Pengelolaan Pendidikan Agama pada Sekolah PAUD/TK, SD, SMP, SMA/SMK (Jakarta, 2011), h. 9.
} 
a. Kemampuan membuat perencanaan pembudayaan pengamalan ajaran agama dan perilaku akhlak mulia pada komunitas sekolah sebagai bagian dari proses pembelajaran agama.

b. Kemampuan mengorganisasikan potensi yang dimiliki sekolah secara sistematis untuk mendukung pembudayaan pengamalan ajaran agama pada komunitas sekolah.

c. Kemampuan untuk menjadi seorang inovator, motivator, fasilitator, pembimbing dan konselor dalam pembudayaan pengamalan ajaran agama pada lingkungan sekolah.

d. Kemampuan menjaga, mengendalikan, dan mengarahkan pembudayaan pengamalan ajaran agama pada lingkungn sekolah serta menjaga keharmonisan hubungan antar pemeluk agama dalam bingkai Negara Kesatuan Republik Indonesia. $^{6}$

Berdasarkan empat indikator di atas inilah yang mengisyaratkan guru Pendidikan Agama Islam wajib memiliki kreativitas yang tinggi dalam memimpin dan mengontrol setiap kegiatan-kegiatan yang dilakukan. Kompetensi leadership yang dimiliki guru Pendidikan Agama Islam ini sangat berperan penting dalam meningkatkan kemampuannya sebagai seorang guru. Guru juga harus mampu mengemas Pendidikan Agama Islam di sekolah yang ramah dan multikultural dengan agama lain sehingga keharmonisan pada diri peserta didik tetap terjaga.

\section{Motivasi Belajar}

Motivasi belajar merupakan faktor psikis. Peranannya yang khas adalah dalam penumbuhan gairah, perasaan, dan semangat untuk bekerja. Motivasi belajar adalah dorongan yang menjadi penggerak dalam diri individu untuk melakukan sesuatu dan mencapai suatu tujuan yaitu untuk mencapai prestasi Motivasi belajar peserta didik adalah keseluruhan daya penggerak psikis di dalam diri peserta didik yang menimbulkan aktivitas belajar atau kegiatan belajar dengan rasa yang bergairah dan bersemangat demi mencapai suatu hasil dan tujuan yang diharapkan.

Motivasi belajar diklasifikasikan dengan berbagai macam pendapat, salah satunya ahli psikologi membagi motivasi menjadi dua macam, yaitu sebagai berikut:

\footnotetext{
${ }^{6}$ Kementerian Agama RI, "Peraturan Menteri Agama No. 16 Tahun 2010 tentang Pengelolaan Pendidikan Agama pada Sekolah" (Jakarta: 2010), h. 9-11.
} 
a. Motivasi Intrinsik

Motivasi intrinsik merupakan motivasi yang berasal dari diri seseorang itu sendiri tanpa ada rangsangan dari luar. Misalnya orang yang gemar membaca, tidak usah ada orang yang mendorong, ia akan mencari sendiri buku-bukunya untuk dibaca. Motif intrinsik juga diartikan sebagai motivasi yang pendorongnya ada kaitan langsung dengan nilai-nilai yang terkandung di dalam tujuan pekerjaan sendiri.

\section{b. Motivasi Ektrinsik}

Motivasi ektrinsik merupakan motivasi yang datang karena adanya perangsangan dari luar, misalnya seperti peserta didik jika akan diadakan ujian mahasiswa akan rajin belajar. Motivasi intinsik ini juga dapat diartikan sebagai motivasi yang terkandung dalam tujuan pekerjaannya. Seperti seorang mahasiswa mau mengerjakan tugas karena takut pada dosen. $^{7}$

Jadi dapat di ambil kesimpulan bahwasanya ada dua macam motivasi, yaitu motivasi inrinsik dan ektrinsik. Intrinsik adalah motivasi yang timbul dalam diri peserta didik sedangkan ektrinsik adalah motivasi yang muncul karena adanya dorongan dari luar, karena adanya kewajiban yang harus ditunaikan.

Adapun indikator dari motivasi belajar menurut Hamzah B Uno adalah adanya hasrat dan keinginan untuk berhasil, adanya dorongan dan kebutuhan dalam belajar, adanya harapan dan cita-cita masa depan, adanya penghargaan dalam belajar, adanya kegiatan yang menarik dalam belajar, dan adanya lingkungan pembelajaran yang kondusif.

\section{HASIL PENELITIAN DAN PEMBAHASAN}

Berdasarkan hasil penelitian yang telah dilakukan terhadap peserta didik kelas XI di SMA Negeri 1 Mamuju yang berjumlah 56 orang peserta didik, maka penulis dapat mengumpulkan data melalui skala yang di isi oleh peserta didik itu sendiri. Tingkat kompetensi leadership (kepemimpinan) guru maka dapat diketahui dengan melakukan kategorisasi yang kemudian dinyatakan sebagai acuan atau norma dalam mengelompokkan skor individu, yang terlebih dahulu ditetapkan batasnya berdasarkan satuan standar deviasi $(\sigma)$ dan mean teoritisnya $(\mu)$. Berdasarkan hasil analisis deskriptif, maka diperoleh standar deviasi sebesar 5,841 dan nilai rata-rata atau meannya sebesar 43,48 , terdapat 8 orang responen yang menunjukkan bahwa kompetensi leadership guru PAI di SMA Negeri 1 Mamuju berada pada kategori rendah dengan persentase sebesar 14,28\%, 34 responen yang menunjukkan bahwa kompetensi leadership guru PAI di SMA Negeri 1 Mamuju berada pada kategori sedang dengan persentase sebesar 60,71\%, dan 14 responden yang menunjukkan bahwa kompetensi leadership guru PAI di SMA Negeri

\footnotetext{
${ }^{7}$ Abdul Rahman Shaleh, Psikologi Suatu Pengantar dalam Perspektif Islam (Cet. IV; Jakarta: Kencana Prenada Media Group, 2009), h. 194.
} 
1 Mamuju berada pada kategori tinggi dengan persentase sebesar 25\%. Sementrara itu jika dilihat dari nilai rata-rata yang diperoleh sebesar 43,48 apabila dimasukkan dalam tiga kategori di atas, maka tingkat kompetensi leadership guru Pendidikan Agama Islam di SMA Negeri 1 Mamuju berada pada interval $38 \leq X<49$ termasuk dalam kategori sedang. Sehingga dapat disimpulkan bahwa guru Pendidikan Agama Islam di SMA Negeri 1 Mamuju memiliki kompetensi leadership termasuk dalam kategori sedang dengan persentase sebesar $60,71 \%$.

Sedangkan hasil analisis deskriptif motivasi belajar peserta didik kelas XI IPA dan XI IPS di SMA Negeri 1 Mamuju, diperoleh standar deviasi sebesar 5,746 dan nilai ratarata atau meannya sebesar 65,85 , terdapat 4 orang responden yang menjukkan bahwa motivasi belajar peserta didik kelas XI di SMA Negeri 1 Mamuju berada pada kategori rendah dengan persentase sebesar $7,14 \%$, terdapat 41 orang responden yang menjukkan bahwa motivasi belajar peserta didik kelas XI di SMA Negeri 1 Mamuju berada pada kategori sedang dengan persentase sebesar 73,21\%, dan terdapat 11 orang responden yang menjukkan bahwa motivasi belajar peserta didik kelas XI di SMA Negeri 1 Mamuju berada pada kategori tinggi dengan persentase sebesar 19,64\%. Sementrara itu jika dilihat dari nilai rata-rata yang diperoleh sebesar 65,85 apabila dimasukkan dalam tiga kategori di atas, maka tingkat motivasi belajar peserta didik kelas XI di SMA Negeri 1 Mamuju berada pada interval $60 \leq X<72$ termasuk dalam kategori sedang. Sehingga dapat disimpulkan bahwa peserta didik kelas XI di SMA Negeri 1 Mamuju memiliki motivasi belajar termasuk dalam kategori sedang dengan persentase sebesar 65,85\%.

Uji normalitas data dimaksudkan apakah data-data yang digunakan berdistribusi normal atau tidak. Pengujian normal tidaknya data pada penelitian ini menggunakan progam statistik SPPS versi 24. Uji normalitas data pada penelitian ini dimaksudkan untuk menguji variabel kompetesi leadership dengan motivasi belajar. Pengujian normal tidaknya data pada penelitian ini menggunakan program SPSS Windows melalui uji Kolmogorov Smirnov.

Tabel 2. Hasil Uji Normalitas

\begin{tabular}{ccc}
\hline Variabel & K-Smirnov & Keterangan \\
\hline $\mathrm{X}-\mathrm{Y}$ & 0,200 & Normal \\
\hline
\end{tabular}

Berdasarkan uji normalitas dengan menggunakan uji Kologorov-Smirnov di atas, diperoleh nilai KSZ signifikansi s untuk variabel X dan Y sebesar 0,200. Hasil yang diperoleh dari $0,05(>0,05)$ maka dapat disimpulkan data berdistribusi normal dan dapat dilanjutkan dengan analisis regresi.

Uji linearitas adalah uji yang akan memastikan apakah data yang dimiliki sesuai garis linier atau tidak. Uji linier dilakukan untuk mengetahui apakah variabel independen memiliki hubungan yang linier dengan variabel dependen. Uji linieritas dalam penelitian ini dilakukan dengan menggunakan analisis varians. Kaidah yang digunakan jika Sig. $<\boldsymbol{\alpha}$ 
$(0,05)$, dan $F_{\text {hitung }}<F_{\text {tabel }}$, maka hubungan kedua variabel linear. Kesimpulan hasil uji linieritas dapat dilhat pada tabel di bawah ini:

Tabel 4 Hasil Uji Liniaritas

\begin{tabular}{cccc}
\hline Variabel & F & Sig & Keterangan \\
\hline X - Y & $\mathbf{2 4 , 1 1 1}$ & $\mathbf{0 , 7 3 6}$ & Linear \\
\hline
\end{tabular}

Berdasarkan tabel di atas hasil analisis SPSS versi 24 for Windows diperoleh uji linearitas persamaan garis regresi dari baris deviation from linearity, yaitu $F_{h i t}(\mathrm{Tc})=$ 24,111 dengan nilai signifikansi sebesar 0,736 dan menggunakan taraf 0,05. Nilai signifikansi yang diperoleh tersebut lebih besar dari $\alpha(0,736>0,05)$. Sehingga dapat disimpulkan bahwa terdapat hubungan yang linear antara kompetensi leadership guru Pendidikan Agama Islam terhadap motivasi belajar peserta didik kelas XI di SMA Negeri 1 Mamuju.

Tabel 5 Hasil Analisis Regresi Sederhana

\begin{tabular}{ccccl}
\hline Rxy & R Square & F & Sig & \multicolumn{1}{c}{ Kesimpulan } \\
\hline 0,406 & $\mathbf{0 , 1 6 5}$ & $\mathbf{1 0 , 6 4 0}$ & $\mathbf{0 , 0 0 2}$ & $\begin{array}{l}\text { Berkolerasi } \\
\text { positif } \\
\text { signifikansi }\end{array}$ \\
\hline
\end{tabular}

Berdasarkan hasil analisis data yang dilakukan, dapat disimpulkan bahwa terdapat pengaruh positif tang signifikan (sig < 0,05) antara kompetensi leadership guru Pendidikan Agama Islam terhadap motivasi belajar peserta didik kelas XI di SMA Negeri 1 Mamuju.

Berdasarkan hasil analisis diperoleh nilai $\mathrm{R}$ sebesar 0,406. Hal ini menunjukkan bahwa terjadi hubungan yang cukup erat antara kompetensi leadership guru Pendidikan Agama Islam terhadap motivasi belajar peserta didik. Analisis determinasi dalam regresi sederhana digunakan untuk mengetahui persentase sumbangan pengaruh variabel independeb $(\mathrm{X})$ terhadap variabel dependen $(\mathrm{Y})$. Koefisien ini menunjukkan seberapa persentase variabel independen yang digunakan dalam model mampu menjelaskan variabel dependen. Jika $\mathrm{R}^{2}$ sama dengan, maka tidak ada sedikitpun persentase sumbangan pengaruh yang diberikan variabel independen terhadap variabel dependen, atau variabel independen yang digunakan dalam model tidak menjelaskan sedikitpun variabel dependen. Sebaliknya jika $\mathrm{R}^{2}$ sama dengan 1, maka persentase sumbangan pengaruh yang diberikan bariabel independen terhadap variabel dependen adalah sempurna atau variabel independen yang digunakan dalam model menjelaskan $100 \%$ variabel dependen.

Berdasarkan tabel diperoleh angka $\mathrm{R}^{2}$ (R Square) sebesar 0,165 atau (16,5\%). Hal ini menunjukkan bahwa persentase sumbangan kompetensi leadership guru Pendidikan Agama Islam terhadap motivasi belajar peserta didik sebesar $16,5 \&$ sedangkan sisinya sebesar $83,5 \%$ dipengaruhi oleh faktor lain di luar dari variabel. 
Kompetensi leadership guru Pendidikan Agama Islam adalah kemampuan yang dimiliki oleh seorang guru dalam mengatur, mengarahkan, membina dan mempengaruhi peserta didik dalam proses pembelajaran maupun dalam pembudayaan pengamalan ajaran agama Islam di sekolah agar tugasnya sebagai seorang guru dapat terlaksana dengan baik sesuai dengan apa yang telah direncanakan. Oleh karena itu perlu diperhatikan indikator dalam mengaplikasikan kompetensi leadership (kepemimpinan) guru antara lain kemampuan membuat perencanaan, kemampuan guru dalam menggorganisasikan potensi unsur sekolah, kemampuan guru menjadi inovator, motivator, fasilitator, pembimbing, dan konselor serta kemampuan guru dalam menjaga, mengendalikan, dan mengarahkan peserta didik di kelas maupun di luar kelas. Kompetensi leadership guru Pendidikan Agama Islam sangat penting untuk dikembangkan. Karena guru Pendidikan Agama Islam diharapkan mampu mengemas Pendidikan Agama Islam yang mengorientasikan dan mempertegas pendidikan agama serta mampu meningkatkan kegairahan peserta didik dalam mengikuti pembelajaran terkhusus pada mata pelajaran Pendidikan Agama Islam.

Kompetensi leadership guru Pendidikan Agama Islam terhadap motivasi belajar peserta didik kelas sangat berkitan erat. Karena guru Pendidikan Agama Islam juga merupakan motivatir, seorang guru harus menjaga semangat dan motivasi peserta didik untuk mengikuti proses belajar, terutama dalam kondisi yang bagi peserta didik adalah hal yang tidak nyaman dan harus mengontrol dirinya sendiri ketika belajar dari rumah. Sehingga kondisi terbaik guru lebih meningkatkan minat dan motivasi belajar peserta didik. Dengan meningkatkan minat dan motivasi belajar peserta didik akan tercipta suasana belajar yang kondusif, kompetatif, dan merangsang pemikiran kritis dan kreatif dari seluruh peserta didik.

Berdasarkan pada uraian di atas, maka dapat disimpulkan bahwa kompetensi leadership guru Pendidikan Agama Islam saling berkaitan erat dengan motivasi belajar peserta didik. Hasil yang diperoleh pada penelitian ini telah sesuai dengan KMA No. 211 tahun 2011 dan teori motivasi belajar menurut hamzah B uno. Penelitian ini juga menerangkan bahwa guru Pendidikan Agama Islam yang memiliki 5 kompetensi yakni sosial, kepribadia, pedagogik, profesional, dan kepemimpinan, merupakan guru yang mantap karen mampu memiliki kompetensi-kompetensi yang harus di miliki oleh seluruh guru terkhusus guru Pendidikan Agama Islam.

Hasil penelitian ini sejalan dengan hasil penelitian terdahulu yang dianggap relevan. Adapun penelitian terdahulu yang membahas tentang pengaruh kompetensi leadership guru Pendidikan Agama Islam terhadap kecerdasan komunikasi interpesonal di SMPN 1 Enrekang yang memperoleh hasil berdasarkan analisis statistik inferensial pengujian hipotesis yang menunjukkan bahwa nilai $(\mathrm{t})$ yang diperoleh dari hasil perhitungan ( $\mathrm{t}_{\text {hitung }}$ ) lebih besar daripada nilai $(\mathrm{t})$ yang diperoleh dari tabel distribusi ( $\left.\mathrm{t}_{\text {tabel }}\right)$. Dari hasil analisis didapattkan taraf nyaa $(\alpha)$ dan nilai tabel sebesar $\alpha=5 \%=0,05 \rightarrow \alpha / 2=0,025$. Kemudian diperoleh hasil analisis $t_{\text {hitung }}=2,835$ sedangkan nilai $t_{\text {tabel }}=2,004$ artinya $\left(t_{\text {hitung }}>t_{\text {tabel }}=\right.$ 
2,835 > 2,004). Dengan demikian kompetensi leadership guru Pendidikan Agama Islam berpengaruh positif terhadap kecerdasan komunikasi interpersonal peserta didik di SMPN 1 Enrekang yakni 75,4\% yang berada pada kategori kuat. Sedangkan sisanya sebesar $24,6 \%$ dipengaruhi oleh variabel lain.

\section{SIMPULAN}

Berdasarkan hasil penelitian dan pembahasan, maka dapat ditarik kesimpulan berdasarkan hasil analisis statistik inferensial kompetensi leadership guru Pendidikan Agama Islam berpengaruh positif terhadap motivasi belajar peserta didik kelas XI di SMA Negeri 1 Mamuju. Sumbangan pengaruh variabel kompetens leadership sebesar $16,5 \%$ sedangkan sisanya sebesar $83,5 \%$ dipengaruhi oleh faktor lain di luar dari variabel.

\section{DAFTAR PUSTAKA}

Republik Indonesia, "Undang-Undang Republik Indonesia Nomor 14 Tahun 2005 tentang Guru dan Dosen”, Jakarta: 2005.

Kementerian Agama Republik Indonesia. Al-Quran dan terjemahnya. Bandung: Diponegoro, 2014.

Kementerian Agama RI. "Peraturan Menteri Agama Nomor. 16 tahun 2010 tentang Pengelolaan Pendidikan Agama pada Sekolah PAUD/TK, SD, SMP, SMA/SMK”. Jakarta, 2011.

Pusat Bahasa Depdikbud. Kamus Besar Bahasa Indonesia. Cet. III; Jakarta: Balai Pustaka, 2005.

Rahman, Abdul Shaleh. Psikologi Suatu Pengantar dalam Perspektif Islam. Cet. IV; Jakarta: Kencana Prenada Media Group, 2009.

Sabir, Ahmad. Strategi Belajar Mengajar \& Micro Teaching. Ciputat: Quantum Teaching, 2007.

Syauful Sahal. Kemampuan Profesional Guru dan Tenaga KePendidikan. Cet. IV; Bandung: Alpabeta, 2013. 